\title{
Analysis of Team Effectiveness at Center of Development and Empowerment for Teachers and Education Personnel Medan
}

\author{
Siti Anom \\ Post Graduate Program in Educational Management, State University of Medan, Indonesia
}

\begin{abstract}
This study tried to describe data of team effectiveness at Center of Development and Empowerment for Teachers and Education Personnel Medan and find out the indicators that are still weak on team effectiveness variables for enhanced in the future. Respondents are trainers and staff with a number of 127 people. Analysis of the data by using descriptive analysis. The results showed the highest scoring team effectiveness is 120, the lowest score is 64, the mean is 102.47 and standard deviation is 13.21, while the ideal highest score is 120, the ideal lowest score is 24, and the ideal mean score is 72 and ideal standard deviation is 16. Data tendency team effectiveness is $73.23 \%$ in the high category, $24.41 \%$ in the enough category and $2.36 \%$ in the low category. Indicators of team effectiveness in this study were achievement of the objectives, quality of work, timeliness of completion and creativity of unit. The weakness indicators of all are is the creativity of unit.

Keywords: creativity of unit, goal achievement, quality of work, team effectiveness, timeliness
\end{abstract}

\subsection{Background}

\section{Introduction}

Effective teams are needed in the organization to achieve the organization's overall goals that led the organization to be a very popular team in the management of the organization. Prior to achieve organizational goals, work teams must first achieve its objectives. Success of the organization related to all aspects of the team and how the performance of the team itself. Teamwork becomes a very important thing for the organization in a state of progress of science and technology considering the jobs carried out increasingly complex in organization and objectives are achieved increasingly high and thus require the expertise and knowledge of employees who can complement each other. Colquit, at. all. (2009) disclose "as a work become more complex, interaction among multiple team members has become more vital because It allows the team to pool complementary knowledge and skills". ${ }^{[1]}$ When more complex work, interactions among team members becomes more vital because the team allows to bring together the skills and knowledge that complement each other. So with the changing environment that requires organizations to change, requires training organizations use teams in the accomplishment of work goals.

Based on observations conducted, It saw visible indication of the ineffectiveness of teamwork at Center of Development and Empowerment for Teachers and Education Personnel, such as: the lack of team members for a few unit/division and the number of members was not comparable with the volume of existing activities in the unit, and this condition giving rise to employees who work overload and caused the expected performance targets were not achieved, stress of employee occurred because they had to complete work deadlines, work too much emphasis on the end result so the group dynamics went on through very little communication and coordination among team members, that caused a low interpersonal relationships, breaking time was less because the time was used to complete the work, the conflicts between teams within the organization because each team chased a target of completion of work, and this caused mistrust between teams within the organization. Meanwhile another phenomenon that happens was excess the number of team members that impressed a lot of time employees were vacant, idle, chat, and use of time at the workplace not for working.

In addition to the information from the above, the results of the external audit of International Standard Organization 9001:2008 in 2011 shown some units of work had not quality of goal yet at Center of Development and Empowerment for Teachers and Education Personnel, namely: Data and Information Section, Department of Building, Department of Automotive, Department of Welding and Metals Fabrication, Department of General Learning. This indicates that the work units had not been effective because there was no of quality goals set to be achieved. In addition, the units had not been able to achieve the specified quality of work were Program Section and Department of Machine.

\subsection{Purpose of Study}

Research is to look at the team effectiveness in the units of work at The Center of Development and Empowerment for Teachers and Education Personnel Medan and gain of viewing indicators of team effectiveness that still can be improved in the future. 


\section{Literature Review}

Slocum \& Hellriegel (2009) stated "a team is a small number of employee with complementary competencies who are committed to common performance goals and working relationship for which they hold themselves mutual accountable. ${ }^{[2]}$ McShane \& Glinow (2007) described "team effectiveness refers to how the team affects the organization, individual team members, and the team existence. Team effectiveness is the extent to which its objectives, achieves the needs and objectives of its members and sustains itself over time." Robbins \& Coulter M. (2009) : "research on team provide insight into the characteristics associated with effective teams....: (1) clear goals, (2) relevant skill, (3) mutual trust, (4) unified commitment, (5) good communication, (6) negotiating skill, (7) appropriate leadership, (8) internal and external support.",4]

Colquit, at. all (2009) said "team characteristic is naturally influence team effectiveness. One aspect of team effectiveness is team performance, which may included metrics such as quantity and quality of goods or service produced, costumer satisfaction, the effectiveness or accuracy of decision, victories, completed report and successful investigation. A second aspect of team effectiveness is team commitment, which is sometimes called team viability. Team viability refers to the likelihood that the team can work together effectively into the future". Similar to Colquit, Keiner R. \& Kinicky A. (2007) said: "two criterions of team effectiveness are team performance and team viability". ${ }^{[5]}$

Gibson at. all. (2009) stated "work team effectiveness demonstrated through: (1) improvement of quality and reduction of time to make decisions, (2) achieving cost-effectiveness in the work process, (3) an increase in morale and creativity of the work" ${ }^{[6]}$ Further Newstrom (2007) said " output of an effective team which includes: (1) performance/productivity improvement, (2) member behaviors, and (3) member attitudes". ${ }^{[7]}$ Further Cohen \& Bailey (19970) categorized the team effectiveness into three major dimensions according to the impact of the team on: (1) performance effectiveness assessed in terms of quantity and quality of output, (2) member attitude and (3) behavioral outcomes) ${ }^{[8]}$ Although the study by Cohen \& Bailey 's long, but the aspects of team effectiveness stated very similar to aspects of team effectiveness proposed by Newstrom, namely that includes: (1) the effectiveness of the prescribed performance of the quantity and quality of output, (2) member attitude and (3) the behavior of members.

Research conducted by Baker, at. all defined that a team consisting of two or more individuals who must interact to achieve one or more company's goals. They also described the characteristics of a team that includes: (1) two or more individuals, (2) a shared and common goals), (3) task interdependency and (4) a productive desired outcomes. In Baker, at all, identify the " three competencies that are central to an effective working team, namely: (1) team knowledge competencies), (2) team skills competencies, (3) team attitude competencies". ${ }^{9]}$ Canon - Bowers at all. in Cohen \& Bailey team competency skills are defined as the capacity to learn to interact with other team members on a minimum level of expertise. They found that 130 of expertise that can be sorted into eight major categories of skills: adaptability, situation awareness, performance monitoring/feedback, leadership, interpersonal relations, coordination, communication, and decision making. Woerkam \& Sanders (2009) in their research on team performance "measures the performance of the team drawn from Ancona and Cald well 's (1992) criteria of team performance.

Four items were used as criteria associated with team output are : (1) efficiency, (2) quality, (3) technical innovation and (4) work excellence. In this research, management or leadership team to evaluate the performance of the team". ${ }^{[10]}$

\section{Method}

Data were collected from 127 respondents, lecturers and staff from 16 units at Centre for Development and Empowerment of Teachers and Education Personnel Medan. Respondents fill out questionnaires distributed of containing indicators of team effectiveness. Descriptive data analysis is presented to see team effectiveness at Centre for Development and Empowerment of Teachers and Education Personnel Medan.

\section{Description Data of Team Effectiveness}

Descriptive Statistics of Team Effectiveness can be seen in Table 1 as below:

Table 1. Descriptive Data of Team Effectiveness

\begin{tabular}{|c|c|c|}
\hline & & Team Effectiveness \\
\hline \multirow{2}{*}{$\mathrm{N}$} & Valid & 127 \\
\hline & Missing & 0 \\
\hline \multicolumn{2}{|c|}{ Mean } & 102.47 \\
\hline \multicolumn{2}{|c|}{ Median } & 104.00 \\
\hline \multicolumn{2}{|c|}{ Mode } & 120 \\
\hline \multicolumn{2}{|c|}{ Std. Deviation } & 13.22 \\
\hline \multicolumn{2}{|c|}{ Variance } & 174.63 \\
\hline
\end{tabular}




\begin{tabular}{|l|r|}
\hline Range & 56 \\
\hline Minimum & 64 \\
\hline Maximum & 120 \\
\hline Sum & 13014 \\
\hline Mean Ideal & 72 \\
\hline Ideal Deviation Standard & 16 \\
\hline Minimum Ideal & 24 \\
\hline Maximum Ideal & 120 \\
\hline
\end{tabular}

Table 2. Frequency Distribution Team Effectiveness Score

\begin{tabular}{|c|c|c|c|c|}
\hline Class & Interval Class & Absolute Frequency & $\begin{array}{c}\text { Relative Frequency } \\
(\mathbf{\%})\end{array}$ & $\begin{array}{c}\text { Cumulative Frequency } \\
(\%)\end{array}$ \\
\hline 1 & $64-71$ & 3 & 2.36 & 2.36 \\
\hline 2 & $72-78$ & 4 & 3.15 & 5.51 \\
\hline 3 & $79-85$ & 9 & 7.09 & 12.6 \\
\hline 4 & $86-92$ & 8 & 6.3 & 18.9 \\
\hline 5 & $93-99$ & 21 & 16.53 & 35.43 \\
\hline 6 & $100-106$ & 30 & 23.62 & 59.05 \\
\hline 7 & $107-113$ & 25 & 19.69 & 78.74 \\
\hline 8 & $114-120$ & 27 & 21.26 & 100 \\
\hline
\end{tabular}

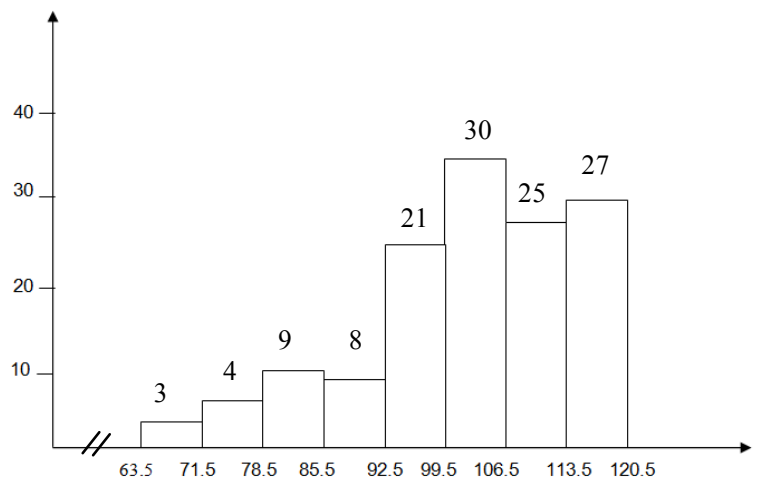

Fig. 1 Histogram of Team Effectiveness Score

Based on the data in Table 1 and 2 above can be seen that the highest score is 120, the lowest score is 64, the mean is 102.47 and standard deviation of is 13.21 , while the ideal highest score is 120 , the ideal lowest score is 24 , and the ideal mean score is 72 and ideal standard deviation is 16 . With guided by the criteria in methodology, team effectiveness tendency is described as follows:

Table 3. Levels of Team Effectiveness Tendency

\begin{tabular}{|c|c|c|c|c|}
\hline Class & Interval Class & $\begin{array}{c}\text { Frequency of } \\
\text { Observation }\end{array}$ & Relative Frequency & Category \\
\hline 1 & $96-$ highest score & 93 & 73.23 & High \\
\hline 2 & $72-95$ & 31 & 24.41 & Enough \\
\hline 3 & $48-71$ & 3 & 2.36 & Low \\
\hline 4 & Lowest score -47 & 0 & 0 & Poor \\
\hline
\end{tabular}

Table 3 above showed $73.23 \%$ respondent is in the high category, $24.41 \%$ respondent is in the enough category and $2.36 \%$ respondent is in the low category. Overall it can be concluded that tendency of team effectiveness is in the high category that mean levels of team effectiveness demonstrated through the achievement of team goals, quality of work, timeliness of completion of the work and creativity of unit is at $76 \%$ to $100 \%$. Team effectiveness data on each unit is presented in Table 4 below: 
Table 4. Average Score Variable Team Effectiveness Each Unit

\begin{tabular}{|c|l|c|}
\hline No & \multicolumn{1}{|c|}{ Work Unit } & Average \\
\hline 1 & Department of Building & 91.54 \\
\hline 2 & Department of Electronics & 107.8 \\
\hline 3 & Department of Automotive & 104.00 \\
\hline 4 & Department of Machine & 94.54 \\
\hline 5 & Department of Welding and Metal Fabrication & 107.17 \\
\hline 6 & Department of General Learning & 106.64 \\
\hline 7 & Department of Information Technology & 101.25 \\
\hline 8 & Department of Electrical & 93.60 \\
\hline 9 & Administrative affairs and Household & 106.41 \\
\hline 10 & Executing Section & 113.43 \\
\hline 11 & Human Resources Development Affair & 97.20 \\
\hline 12 & Program Section & 106.83 \\
\hline 13 & Data and Information Section & 107.25 \\
\hline 14 & Evaluation Section & 102.80 \\
\hline 15 & Planning and Budgeting Affair & 101.13 \\
\hline 16 & Hostel Affair & 105.20 \\
\hline
\end{tabular}

Based on the data trend of team effectiveness and team effectiveness average score of each unit, then the trend of the data of all unit, $13(81.25 \%)$ units were in high category and $3(18.75 \%)$ units were in enough category. The data processing team effectiveness for each indicator are presented in Table 5 below:

Table 5. Average Indicators of Team Effectiveness

\begin{tabular}{|c|l|l|c|}
\hline No & \multicolumn{1}{|c|}{ Aspect } & \multicolumn{1}{|c|}{ Indicator } & Indicator Average \\
\hline I & \multirow{2}{*}{ Work unit performance } & a. Achievement of the objectives & 4.35 \\
\cline { 3 - 4 } & & b. Quality of work & 4.34 \\
\hline & & c. Timeliness of completion work & 4.29 \\
\hline & & d. Creativity of unit & 3.84 \\
\hline
\end{tabular}

Of the four indicators of team effectiveness in this study, creativity of unit is the weakness indicator, It implies that the team effectiveness can be still improved, especially with the increasing creativity of unit, further all indicators of team effectiveness could be enhanced up to the maximum results. Winardi (2003:247) in Suryana Y, Bayu K., revealed that "creativity is the ability to develop new ideas and find new ways of looking at problems and opportunities." Hubeis (2005) in Suryana Y, Bayu K., (2010:213) states "creativity is a subjective judgment and special about everything new and is the result of individual and collective behavior". [11] Thus creativity is very important thing to do by the team to create opportunities and new things all of which are aimed at improving the performance of the team in particular and the institution in general. However, the lack of creativity in this institution may be caused by the nature of employment in the government employee who tend to be routine work and wait for the given programs so that team members drown in a routine activity, so oblivious to create and explore something new in doing the job and their duties. Regardless of the problem, opportunities for creativity remain open in this institution especially like the trainers which is always an opportunity to make and create models of new teaching and making teaching aids, for example in the form of a prototype so the need for training in order to create creativity for employees at Center of Development and Empowerment for Teachers and Education Personnel Medan.

\section{Conclusion}

The effectiveness of the data distribution team at the Center of Development and Empowerment for Teachers and Education Personnel Medan showed 93 people (73.23\%) in the high category, 31 people (24.24\%) in enough category and 3 people $(2.36 \%)$ in the low category. Overall team effectiveness at this institution tends to high category. Team leaders and team members have reached a high level of effectiveness of achieving team goals both in quality and quantity as well as the completion of work on time. Tendency of the data unit is 13 $(81.25 \%)$ units tend to work in the high category and $3(18.75 \%)$ units tend to be in enough category. Of the four indicators variables work team effectiveness, the lowest indicator is creativity of unit. Creativity of unit need to be improved to enhanced team effectiveness.

\section{References:}

[1]. Colquit, LePine. Wesson. 2009. Organizational Behavior, Improving Performance and Commitment in the Workplace, New York: McGraw-Hill.p.373-393

[2] Slocum, Hellriegel. 2009. Principles of Organizational Behavior. South Western: Cengage Learning.p.321

[3]. McShane, Glinow Von. 2007. Organizational Behavior (Essential). New York. McGraw-Hill, p.135 
[4] Robbins, Coulter M., Management. New York: McGraw-Hill.p.117

[5]. Keitner Robert \& Kinicki Angelo., 2007. Organizational Behavior. New York: McGraw-Hill, p.344

[6]. Gibson, Ivancevich, Donnelly, Konopaske, 2009. Organizational Behavior, Structure, Process. New York: McGraw-Hill,p.252

[7]. Newstrom W. John. 2007. Organizational Behaviour, Human Behavior ar Work. New York: McGraw-Hill, p.304

[8]. Cohen, Bailey. 1997. What Makes Team Work: Group Effectiveness Research From The Shop Floor to The Executive Suite. Journal of Management (online) Vol. 23, No. 3, p.243 (http: www.JAIPress.com, accessed on January 22, 2012)

[9] Baker P. David, Horvath Lisa, Campion Michael, Offerman Lynn, Salas Eduardo, Teamwork: Status Memorandum. Working Draft Adult Literacy and Life Skill. (online), p.5 (http:www pdfcast.org/download, accessed on January 22, 2012) .

[10]. Woerkam, Sanders. 2010. The Romance of Learning from Disagreement. The Effect of Cohesiveness and Disagreement on Knowledge Behaviour and Individual Performance Within Teams. Journal of Organizational Behavior. (online), Vol. 25, No. 1, hal. 139-149, (http: www.JBusPsychol.com, accessed on January 22, 2012).

[11] Suryana Y, Bayu K,. 2010. Kewirausahaan. Jakarta: Kencana Prenada Media Group. p.213 